\title{
p38/AP-1 Pathway in Lipopolysaccharide-Induced Inflammatory Responses Is Negatively Modulated by Electrical Stimulation
}

\author{
Deok Jeong, ${ }^{1}$ Jaehwi Lee, ${ }^{2}$ Young-Su Yi, ${ }^{1}$ Yanyan Yang, \\ Kyoung Won Kim, ${ }^{3}$ and Jae Youl Cho ${ }^{1}$ \\ ${ }^{1}$ Department of Genetic Engineering, Sungkyunkwan University, Suwon 440-746, Republic of Korea \\ ${ }^{2}$ College of Pharmacy, Chung-Ang University, Seoul 156-756, Republic of Korea \\ ${ }^{3}$ Research Institute, Human Nanoelectrotech Co. Ltd., Seoul 151-050, Republic of Korea \\ Correspondence should be addressed to \\ Kyoung Won Kim; ephedral@naver.com and Jae Youl Cho; jaecho@skku.edu
}

Received 3 February 2013; Accepted 15 March 2013

Academic Editor: Yves Denizot

Copyright (C) 2013 Deok Jeong et al. This is an open access article distributed under the Creative Commons Attribution License, which permits unrestricted use, distribution, and reproduction in any medium, provided the original work is properly cited.

Electrical stimulation with a weak current has been demonstrated to modulate various cellular and physiological responses, including the differentiation of mesenchymal stem cells and acute or chronic physical pain. Thus, a variety of investigations regarding the physiological role of nano- or microlevel currents at the cellular level are actively proceeding in the field of alternative medicine. In this study, we focused on the anti-inflammatory activity of aluminum-copper patches (ACPs) under macrophagemediated inflammatory conditions. ACPs generated nanolevel currents ranging from 30 to $55 \mathrm{nA}$ in solution conditions. Interestingly, the nanocurrent-generating aluminum-copper patches (NGACPs) were able to suppress both lipopolysaccharide(LPS-) and pam3CSK-induced inflammatory responses such as NO and PGE $_{2}$ production in both RAW264.7 cells and peritoneal macrophages at the transcriptional level. Through immunoblotting and immunoprecipitation analyses, we found that p38/AP-1 could be the major inhibitory pathway in the NGACP-mediated anti-inflammatory response. Indeed, inhibition of p38 by SB203580 showed similar inhibitory activity of the production of TNF- $\alpha$ and $\mathrm{PGE}_{2}$ and the expression of TNF- $\alpha$ and COX-2 mRNA. These results suggest that ACP-induced nanocurrents alter signal transduction pathways that are involved in the inflammatory response and could therefore be utilized in the treatment of various inflammatory diseases such as arthritis and colitis.

\section{Introduction}

Inflammation is a basic signal that prompts the body to clear infecting or invading pathogens from our tissues. This response is naturally present at birth; thus, it is classified as an innate immune response $[1,2]$. Phagocytes such as macrophages and dendritic cells are the principal cells that manage the inflammatory response. Currently, numerous cellular events involved in inflammation have been identified. Thus, many types of soluble factors, including cytokines (e.g., tumor necrosis factor (TNF)- $\alpha$ ), chemokines, and inflammatory mediators (including nitric oxide (NO) and prostaglandin $\mathrm{E}_{2}\left(\mathrm{PGE}_{2}\right)$ ), control autocrine and paracrine types of immune cell activation, cell-to-cell interactions, and the migration of various immune cells, including macrophages, neutrophils, and $\mathrm{T}$ and $\mathrm{B}$ lymphocytes. Despite the positive role of inflammation, hyperactive and long-lasting inflammatory states are critically linked to the onset of various serious diseases, including cancer, diabetes, atherosclerosis, and arthritis [3-6]. Therefore, returning upregulated chronic inflammatory responses to baseline levels could be an important strategy to prevent multiple diseases.

The molecular aspects of the inflammatory response are principally studied in macrophages by activating pattern recognition receptors such as Toll-like receptor (TLR) 4 and TLR2 through treatment with their ligands, lipopolysaccharide (LPS) and poly(I:C), respectively [7]. Over the course of many studies, multiple intracellular signaling pathways that are composed of nonreceptor protein tyrosine kinases 
and mitogen-activated protein kinases (MAPKs), including ERK (extracellular signal-related kinase), p38, and JNK (CJun $\mathrm{N}$-terminal kinase), have been identified as the upstream machinery for the activation and translocation of transcription factors (e.g., nuclear factor (NF) $\kappa \mathrm{B}$ and activator protein (AP)-1) into the nucleus $[8,9]$. Finally, proinflammatory genes encoding tumor necrosis factor (TNF) $-\alpha$, inducible NO synthase (iNOS), and cyclooxygenase (COX)-2 are transcribed by these factors in activated macrophages [3, 10-12].

Various forms of radiation, including far-infrared and ultraviolet radiation, have been shown to modulate cellular and physiological responses in many different fields [13]. For example, far-infrared radiation is widely applied to promote health, treat vascular-related disorders, and preserve food [14]. In addition, improvements in endothelial cell function, enhancements of blood circulation in the skin, and increased survival among arteriovenous-fistula hemodialysis patients have also been demonstrated through the use of this radiation $[15,16]$. Compared with these reports, the use of electrical stimulation is limited due to side effects. The most popular research area for electrical stimulation is the search for a method to rehabilitate neural degeneration after spinal cord injury [17]. Furthermore, acute and chronic pain and the inflammatory response are conditions that electrical stimulation has recently been employed to relieve [18-20]. Moreover, it has been reported that a weak direct current that is generated using metals such as silver at the positive electrode is able to suppress the growth of bacteria and fungi $[21,22]$. Although a variety of curative methods that use microcurrents have been employed against many different types of diseases, the ameliorative mechanism of electrical stimulation has not been fully elucidated at the molecular level. Therefore, in this study, we aimed to understand the mechanisms through which electrical stimulation is able to suppress inflammatory responses at the cellular and molecular levels using a nanocurrent-generating aluminum-copper patch (NGACP).

\section{Materials and Methods}

2.1. Materials. The nanocurrent-generating aluminum-copper patch (NGACP) was obtained from Human Nano Electrotech (Seoul, Korea). Pam3CSK; 3-(4,5-dimethylthiazol2-yl)-2,5-diphenyltetrazolium bromide, a tetrazole (MTT); and lipopolysaccharide (LPS, E. coli 0111:B4) were purchased from Sigma Chemical Co. (St. Louis, MO, USA). SB203580 was obtained from Calbiochem (La Jolla, CA, USA). Enzyme immunoassay (EIA) kits and enzyme-linked immunosorbent assay (ELISA) kits for determining $\mathrm{PGE}_{2}$ and TNF- $\alpha$ levels were purchased from Amersham (Little Chalfont, Buckinghamshire, UK). Fetal bovine serum and RPMI 1640 were obtained from GIBCO (Grand Island, NY, USA). RAW264.7 and HEK293 cells were procured from the ATCC (Rockville, MD, USA). All other chemicals were of analytical grade and obtained from Sigma. Phosphospecific or total antibodies against c-Fos, c-Jun, extracellular signal-related kinase (ERK), c-Jun N-terminal kinase (JNK), p38, mitogen-activated protein kinase kinase 3/6 (MKK3/6),
MKP-1, lamin A/C, and $\beta$-actin were obtained from Cell Signaling (Beverly, MA, USA).

2.2. Preparation of Aluminum-Copper Patch and Measurement of the Electrical Potential. Copper and aluminum patches used in the present study were obtained from a commercial source (Pharmdi Band) manufactured under the method below. Copper having a purity of $99.92 \%$ was cold-rolled to produce a thin metal plate with a thickness of $100 \mu \mathrm{m}$ and cut into a square $\left(1 \mathrm{~cm}^{2}\right)$ and used as a cathode. Separately, aluminum patch $\left(99.70 \%\right.$ purity, $17 \mu \mathrm{m}$ thickness, $1 \mathrm{~cm}^{2}$ area) was produced using the same procedure and used as an anode. For measuring electrical potential, two electrodes (cathode and anode) were attached to the main body of a multimeter (DMM 4040, Tektronix, USA). The electrodes were immersed in cell culture media or saline and placed in a polypropylene dish, and the electric current values were monitored. Separately, nanocurrent-generating aluminum and copper patches (NGACPs) with surface areas of $0.4 \mathrm{~cm}^{2}$ were held on the bottom surface of the dish using doublesided adhesive tape, and cell culture media or saline $(10 \mathrm{~mL})$ was added to the dish. Then, the cathodes and anodes were firmly touched to the aluminum and copper patches, and the electric current values were obtained.

2.3. Animals. C57BL/6 male mice (6- to 8-week old, 17 to $21 \mathrm{~g}$ ) were obtained from DAEHAN BIOLINK (Chungbuk, Korea) and housed in plastic cages under conventional conditions. Water and pellet diets (Samyang, Daejeon, Korea) were available ad libitum. Studies were performed in accordance with the guidelines established by the Sungkyunkwan University Institutional Animal Care and Use Committee.

2.4. Preparation of Peritoneal Macrophages. Peritoneal exudates were obtained from C57BL/6 male mice (7- to 8-week old, 17 to $21 \mathrm{~g}$ ) by lavaging four days after intraperitoneal injection of $1 \mathrm{~mL}$ of sterile $4 \%$ thioglycolate broth (Difco Laboratories, Detroit, MI, USA) as previously reported [23]. After washing with RPMI 1640 medium containing 2\% FBS, peritoneal macrophages $\left(1 \times 10^{6}\right.$ cells $\left./ \mathrm{mL}\right)$ were plated in $100 \mathrm{~mm}$ tissue culture dishes for $4 \mathrm{~h}$ at $37^{\circ} \mathrm{C}$ in a $5 \% \mathrm{CO}_{2}$ humidified atmosphere.

2.5. Cell Culture. Peritoneal macrophages and cell lines (RAW264.7 and HEK293 cells) were cultured with RPMI 1640 medium supplemented with $10 \%$ heat-inactivated fetal bovine serum (Gibco, Grand Island, NY, USA), glutamine, and antibiotics (penicillin and streptomycin) at $37^{\circ} \mathrm{C}$ under $5 \% \mathrm{CO}_{2}$. For each experiment, the cells were detached with a cell scraper. At the cell density that was used for the experiments $\left(2 \times 10^{6}\right.$ cells $\left./ \mathrm{mL}\right)$, the proportion of dead cells was less than $1 \%$ as measured by Trypan blue dye exclusion.

2.6. NO, $P G E_{2}$, and TNF- $\alpha$ Production. After recuperation of RAW264.7 cells or peritoneal macrophages $\left(1 \times 10^{6}\right.$ cells $\left./ \mathrm{mL}\right)$ for $18 \mathrm{~h}$, the cells were placed with NGACPs for $30 \mathrm{~min}$ and were further incubated with LPS $(1 \mu \mathrm{g} / \mathrm{mL})$ for $24 \mathrm{~h}$. The 
TABLE 1: Sequences of primers used in semiquantitative and real-time PCR analyses.

\begin{tabular}{|c|c|c|}
\hline Name & & Sequence $\left(5^{\prime}\right.$ to $\left.3^{\prime}\right)$ \\
\hline \multicolumn{3}{|c|}{ Real-time PCR } \\
\hline \multirow{2}{*}{ iNOS } & $\mathrm{F}$ & GGA GCC TTT AGA CCT CAA CAG A \\
\hline & $\mathrm{R}$ & TGA ACG AGG AGG GTG GTG \\
\hline \multirow{2}{*}{ COX-2 } & $\mathrm{F}$ & GGGAGTCTGGAACATTGTGA \\
\hline & $\mathrm{R}$ & GCACATTGTAAGTAGGTGGA \\
\hline \multirow{2}{*}{ TNF- $\alpha$} & $\mathrm{F}$ & TGC CTA TGT CTC AGC CTC TT \\
\hline & $\mathrm{R}$ & GAG GCC ATT TGG GAA CTT CT \\
\hline \multirow{2}{*}{ GAPDH } & $\mathrm{F}$ & CAA TGA ATA CGG CTA CAG CAA C \\
\hline & $\mathrm{R}$ & AGG GAG ATG CTC AGT GTT GG \\
\hline \multicolumn{3}{|c|}{ Semiquantitative RT-PCR } \\
\hline \multirow{2}{*}{ TNF- $\alpha$} & $\mathrm{F}$ & TTGACCTCAGCGCTGAGTTG \\
\hline & $\mathrm{R}$ & CCTGTAGCCCACGTCGTAGC \\
\hline \multirow{2}{*}{ IL- $1 \beta$} & $\mathrm{F}$ & CAGGATGAGGACATGAGCACC \\
\hline & $\mathrm{R}$ & CTCTGCAGACTCAAACTCCAC \\
\hline \multirow{2}{*}{ IL-6 } & $\mathrm{F}$ & GTACTCCAGAAGACCAGAGG \\
\hline & $\mathrm{R}$ & TGCTGGTGACAACCACGGCC \\
\hline \multirow{2}{*}{ COX-2 } & $\mathrm{F}$ & CACTACATCCTGACССАСТT \\
\hline & $\mathrm{R}$ & ATGCTCCTGCTTGAGTATGT \\
\hline \multirow{2}{*}{ iNOS } & $\mathrm{F}$ & CCCTTCCGAAGTTTCTGGCAGCAGC \\
\hline & $\mathrm{R}$ & GGCTGTCAGAGCCTCGTGGCTTTGG \\
\hline \multirow{2}{*}{ IFN- $\beta$} & $\mathrm{F}$ & CСАССАСАGСССТСТССАТСААСТАТ \\
\hline & $\mathrm{R}$ & CAAGTGGAGAGCAGTTGAGGACATC \\
\hline \multirow{2}{*}{ IL-12 } & $\mathrm{F}$ & CAGAAGCTAACCATCTCCTGGTTTG \\
\hline & $\mathrm{R}$ & TCCGGAGTAATTTGGTGCTTCACAC \\
\hline \multirow{2}{*}{ GAPDH } & $\mathrm{F}$ & CACTCACGGCAAATTCAACGGCAC \\
\hline & $\mathrm{R}$ & GACTCCACGACATACTCAGCAC \\
\hline
\end{tabular}

F: forward, R: reverse.

inhibitory effect of NGACPs treatment on $\mathrm{NO}, \mathrm{PGE}_{2}$, and TNF- $\alpha$ production was determined by analyzing $\mathrm{NO}, \mathrm{PGE}_{2}$, and TNF- $\alpha$ levels with the Griess reagent and enzyme-linked immunosorbent assay (ELISA) kits as previously described $[24,25]$.

2.7. Cell Viability Test. After preincubation of RAW264.7 cells $\left(1 \times 10^{6}\right.$ cells $\left./ \mathrm{mL}\right)$ for $18 \mathrm{~h}$, NGACPs was added to the cells, and the cells were incubated for $24 \mathrm{~h}$. The cytotoxic effect of the peptide $\mathrm{K} 5$ was then evaluated using a conventional MTT assay as previously reported $[26,27]$. At $3 \mathrm{~h}$ prior to culture termination, $10 \mu \mathrm{L}$ of MTT solution $(10 \mathrm{mg} / \mathrm{mL}$ in phosphate buffered saline, $\mathrm{pH}$ 7.4) was added to each well, and the cells were continuously cultured until termination of the experiment. The incubation was halted by the addition of $15 \%$ sodium dodecyl sulfate into each well, thus solubilizing the formazan [28]. The absorbance at $570 \mathrm{~nm}\left(\mathrm{OD}_{570-630}\right)$ was measured using a Spectramax 250 microplate reader.

2.8. $m R N A$ Analysis Using Real-Time Reverse Transcriptase Polymerase Chain Reaction (RT-PCR). To determine the cytokine mRNA expression levels, total RNA was isolated from LPS-treated RAW264.7 cells using TRIzol Reagent (Gibco BRL) according to the manufacturer's instructions.
Total RNA was stored at $-70^{\circ} \mathrm{C}$ until use. Quantification of mRNA was also performed using real-time RT-PCR with SYBR Premix Ex Taq (Takara, Japan) and a real-time thermal cycler (Bio-Rad, Hercules, CA, USA), as stated earlier [29, 30]. The results were expressed as the ratio of the optical density to GAPDH. To qualitatively evaluate mRNA expression levels, semiquantitative RT reactions were conducted as stated in advance [31]. The primers (Bioneer, Daejeon, Korea) used are indicated in Table 1.

2.9. Preparation of Total Lysates and Nuclear Extracts and Immunoblotting. Preparation of total lysates and nuclear extracts from LPS-treated RAW264.7 cells that had been pretreated with NGACPs was performed using a previously published method [32]. Immunoblot analysis of the levels of phosphorylated or total transcription factors (p65, c-Jun, and c-Fos), lamin A/C, MAPKs (ERK, p38, and JNK), MKK 3/6, MKP-1, and $\beta$-actin was performed according to the cited technique $[33,34]$.

2.10. Statistical Analysis. Data (Figures 1, 2, and 4), expressed as the means \pm standard deviation (SD), were calculated from one $(n=6)$ of two independent experiments. Other data are representative of three different experiments with similar 




Normal

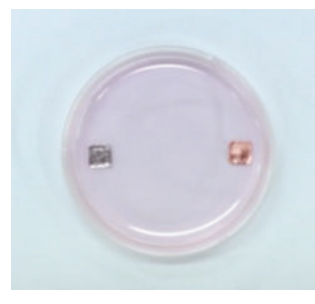

NGACPs



(b)

(a)

FIGURE 1: Current induction levels of aluminum-copper patch (ACP) in cell-plated medium. (a) Photos of ACPs were taken with a digital camera. (b) The electrical field was measured using a multimeter as described in Section 2.

results. For statistical comparisons, the results were analyzed using analysis of variance/Scheffe's post hoc test and the Kruskal-Wallis/Mann-Whitney test. All $P$ values $<0.05$ were considered statistically significant. All of the statistical tests were carried out using the computer program SPSS (SPSS Inc., Chicago, IL, USA).

\section{Results and Discussion}

It has been reported that electrically generated silver ions increase weak direct currents and are able to inhibit bacterial and fungal growth $[21,22]$. Because aluminum and copper are also metals that strongly release electrically generated ions, we first measured the levels of current in a saline solution, RPMI 1640 medium, and cell-cultured medium in the presence or absence of these metals. As Figure 1 shows, both aluminum and copper soaked in these solutions (Figure 1(a)) distinctly increased the nanolevel current from approximately $35 \mathrm{nA}$ to $55 \mathrm{nA}$ (Figure 1(b)). No increase was observed under normal conditions. Therefore, this result strongly suggested that a copper and aluminum patch in cell-plating culture medium could alter the environment for cellular responses by enhancing a nanocurrent. Because electric stimulation has been demonstrated to ameliorate chronic pain and inflammatory symptoms in vivo [18-20], we examined whether NGACP treatment could modulate the in vitro inflammatory responses of macrophages, and we explored the inhibitory mechanism of NGACP activity.

Interestingly, NGACP exposure strongly suppressed the production of NO from both RAW264.7 cells (Figure 2(a)) and peritoneal macrophages (Figure 2(b)) that had been stimulated with LPS or pam3CSK. Furthermore, NGACP treatment inhibited the release of $\mathrm{PGE}_{2}$ under the same conditions (Figure 2(c)), which implied that NGACP treatment could affect both LPS- and pam3CSK-induced inflammatory responses. Analyses of the morphology of RAW264.7 and HEK293 cells (Figure 2(d)) and tests of their viability (Figure 2(e)) clearly demonstrated that NGACP treatment was not cytotoxic to these cells, which indicated that the NO-inhibitory activity of the NGACPs was not caused by nonspecific cytotoxicity.

To confirm the inhibitory effect on $\mathrm{NO}$ and $\mathrm{PGE}_{2}$ production, we first assessed inhibition at the transcriptional level. The mRNA levels of various inflammatory genes such as COX-2, iNOS, TNF- $\alpha$, IL- $1 \beta$, IL-6, IFN- $\beta$, and IL-12 were measured under NGACP treatment conditions. As Figure 3(a) shows, expression of most of the inflammatory genes except IL-1 $\beta$ was suppressed by NGACP treatment. Furthermore, real-time RT-PCR analysis showed similar inhibitory patterns on the expression of iNOS and COX2 (Figure 3(b)), which implied that transcriptional activation of LPS-induced inflammatory responses was targeted by NGACP treatment. Because transcriptional activation is regulated by the nuclear translocation of various transcription factors such as NF- $\kappa \mathrm{B}, \mathrm{AP}-1, \mathrm{CREB}$, and STAT-1 [35], the nuclear levels of these proteins were then examined. As Figure 4(a) confirms, NGACP treatment clearly blocked the nuclear translocation of c-Jun at $6 \mathrm{~h}$, while the other transcription factors were also inhibited based on the results for lamin A/C. In addition, AP-1-mediated luciferase activity was also suppressed by NGACP (data not shown). Because cJun is a representative transcription factor that is regulated by ERK, JNK, and p38 [36], we examined whether the activation of these enzymes could be blocked by NGACP treatment through analysis of their phosphorylation levels. As Figure 4(b) reveals, the phosphorylation of p38 at $1 \mathrm{~h}$ was strongly inhibited by NGACP treatment. In particular, because phosphorylation of MKK3/6, an upstream enzyme that phosphorylates p38 [37], was not blocked (Figure 4(c)) and the protein level of phospho-p38 diphosphatase, MKP1 [38], was not enhanced (Figure 4(d)), NGACP treatment seems to directly target MKK3/6, although a specific enzyme 



(a)



(b)
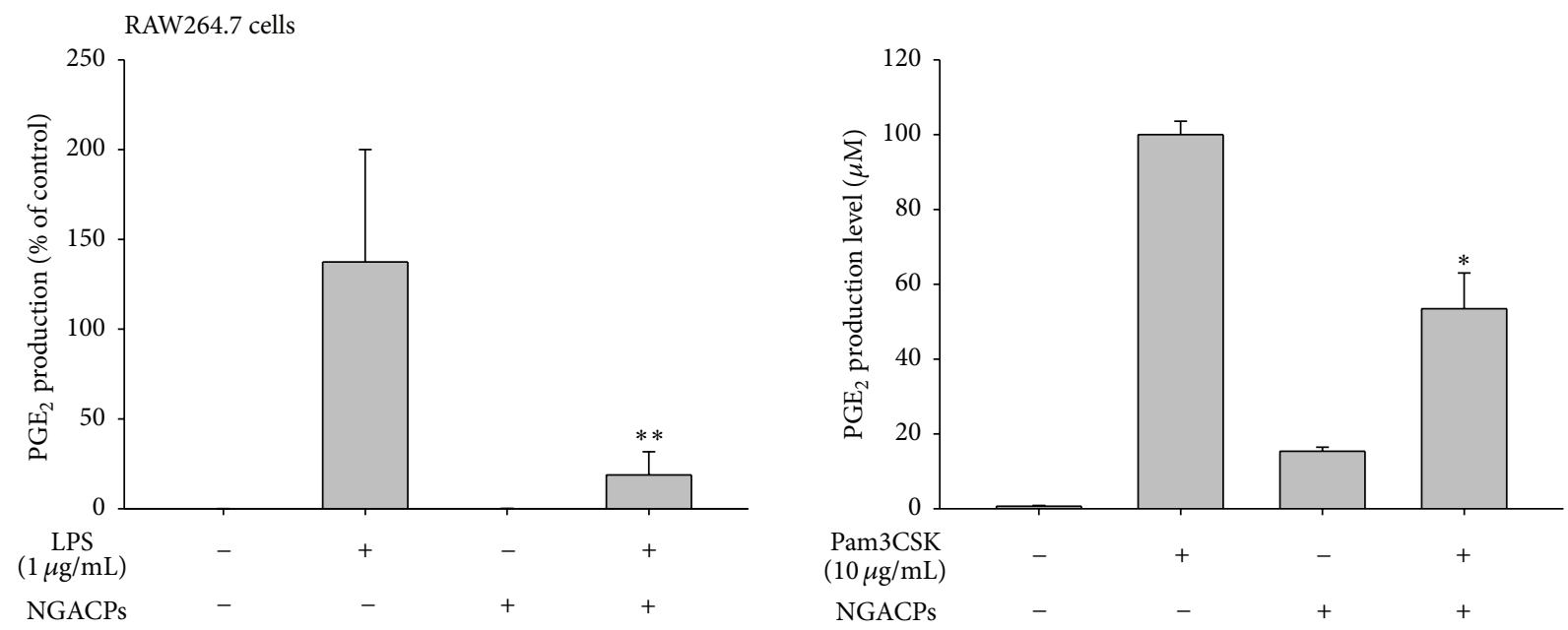

(c)

Figure 2: Continued. 




(d)
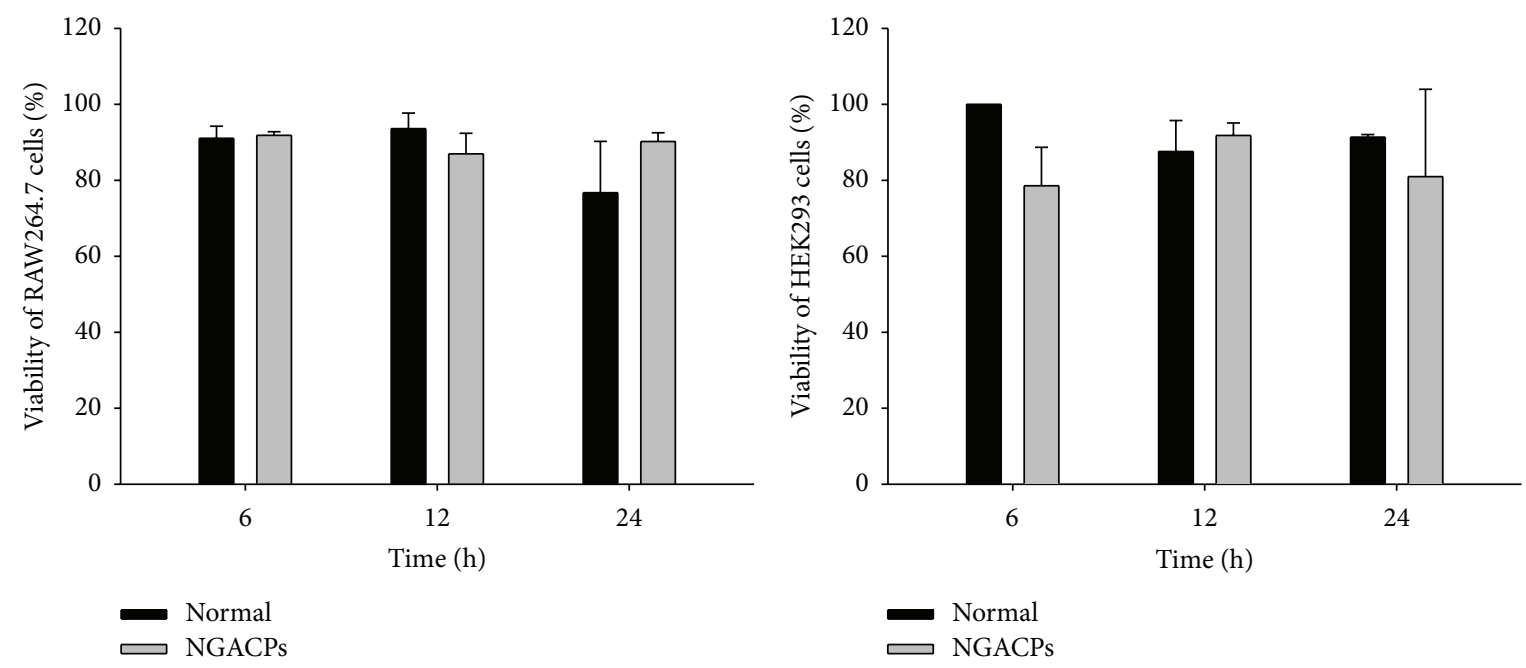

(e)

FIGURE 2: Effect of nanocurrent-generating ACPs (NGACPs) treatment on the production of inflammatory mediators. ((a), (b), and (c)) The levels of $\mathrm{NO}$ and $\mathrm{PGE}_{2}$ were determined using a Griess assay and EIA with culture supernatants from RAW264.7 cells or peritoneal macrophages that had been treated with NGACP and LPS $(1 \mu \mathrm{g} / \mathrm{mL})$ or pam3CSK $(10 \mu \mathrm{g} / \mathrm{mL})$ for 6 or $24 \mathrm{~h}\left(\mathrm{NO}_{\text {and PGE }}\right.$, resp.). (d) Morphological alterations in RAW264.7 cells and HEK293 cells were photographed using a digital camera. (e) The viability of RAW264.7 and HEK293 cells was determined using an MTT assay. ${ }^{*} P<0.05$ and ${ }^{* *} P<0.01$ compared to control.

assay would be required to obtain better evidence. In agreement with this finding, signaling complex formation between p38 and MKK3 was also defective, as demonstrated through immunoprecipitation and immunoblotting analyses (Figure 4(e)). Therefore, these results strongly suggest that the MKK3/p38 pathway could be the major inhibitory target of NGACP treatment. Finally, we confirmed the functional significance of p38 in the inflammatory response by using a specific inhibitor, SB203580 (SB), on LPS-activated RAW264.7 cells. SB also strongly suppressed the expression of COX-2 and TNF- $\alpha$ mRNA, as assessed using RT- and real-time PCR (Figure 5(a)) and inhibited the release of TNF- $\alpha$ and PGE $_{2}$ (Figure 5(b)), which is in agreement with previously reported results [39].

The mechanism through which NGACP treatment can affect the p38-mediated AP-1 activation signaling cascade is 


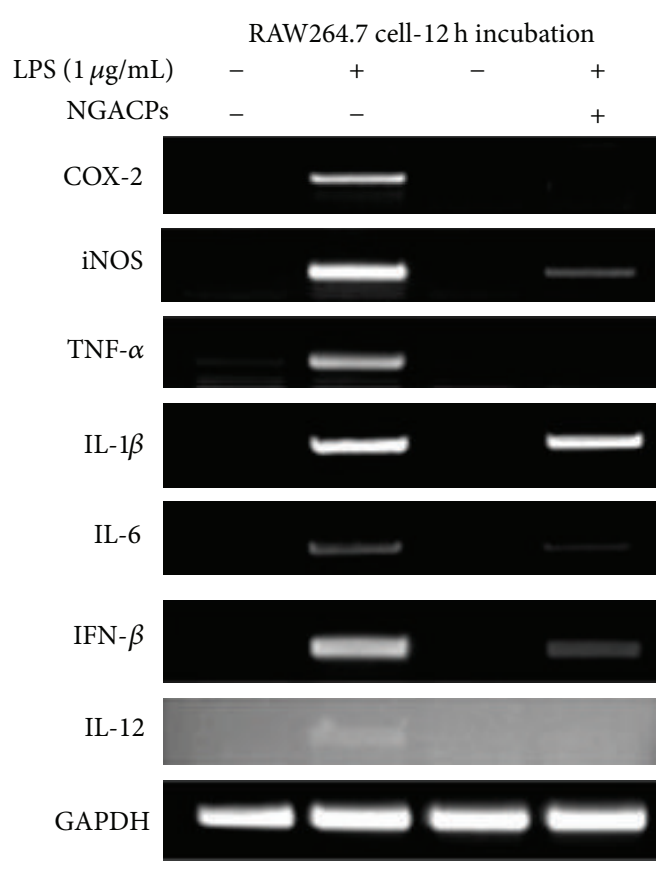

(a)
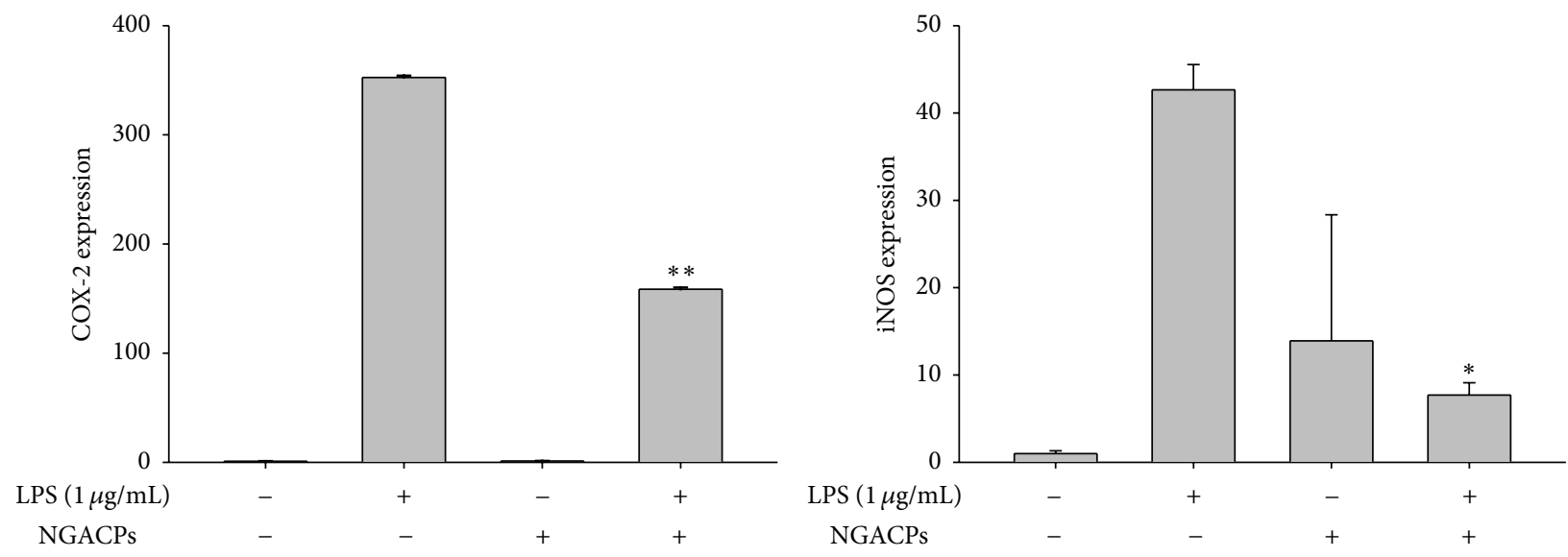

(b)

FigURE 3: Effect of NGACP treatment on the expression of proinflammatory mRNA. ((a) and (b)) The mRNA levels of proinflammatory genes (COX-2, iNOS, TNF- $\alpha$, IL-1 $\beta$, IL- 6 , IFN- $\beta$, and IL-12) were determined using semiquantitative RT-PCR or real-time PCR. ${ }^{*} P<0.05$ and ${ }^{* *} P<0.01$ compared to control.

not yet clear. Similar to our results (Figure 4(b)), it has been reported that $\mathrm{Zn} / \mathrm{Cu}$-derived microcurrents are able to suppress NF- $\kappa \mathrm{B}$ via crosstalk with p38 in primary keratinocytes that have been stimulated with TNF- $\alpha$ [40]. In contrast, under normal conditions, electrical stimulation increased the phosphorylation of p38 in keratinocytes and human mesenchymal stromal cells $[40,41]$, which implies that inhibition of p38 signaling could be a stimulus-dependent phenomenon. Thus, NGACP treatment only suppressed the phosphorylation of p38 that was induced by treatment with LPS as a TLR4 ligand [42] and inhibited $\mathrm{NO}$ and $\mathrm{PGE}_{2}$ production during exposure to LPS and pam3CSK, which is a TLR2 ligand [42]. Furthermore, electrical stimulation has been shown to activate or inhibit the activities of other enzymes such as PI3K and AKT in muscle and liver cells $[43,44]$, ERK in human mesenchymal stromal cells [41], and JNK1/2 in the injured kidneys of Alport mice [45]. In the case of p38 activation, it has been found that hydrogen peroxide that was produced by a $\mathrm{Zn} / \mathrm{Cu}$-triggered microcurrent plays a critical role in phosphorylation [40]. However, the inhibition of LPS-induced p38 activation does not appear to be explained by this event. The fact that NGACP treatment 


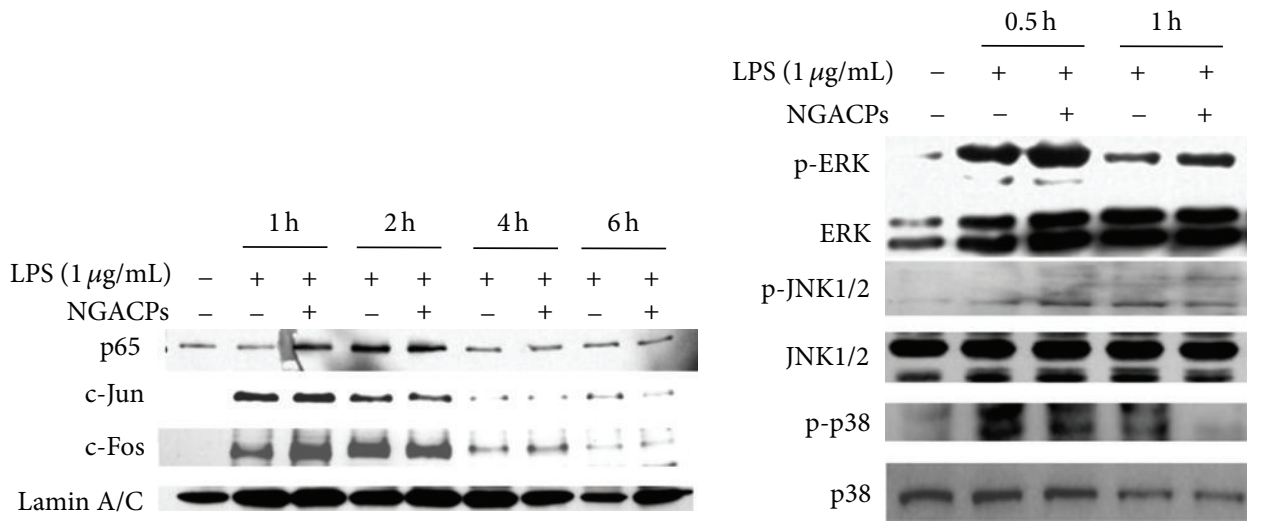

(a)

(b)

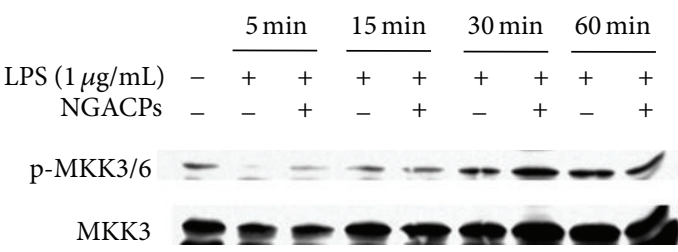

(c)

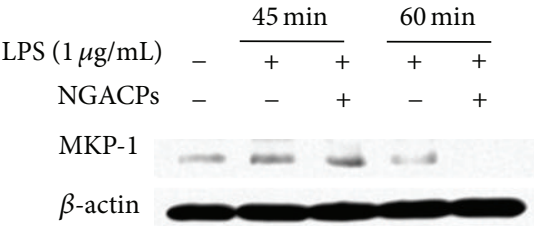

(d)

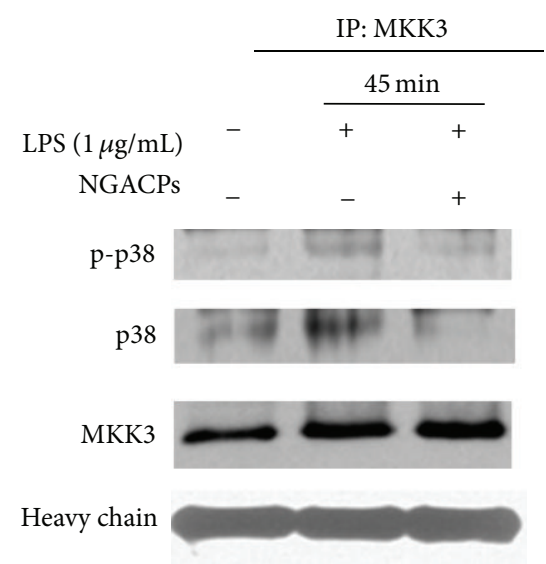

(e)

FIGURE 4: Effect of NGACP on the activation of transcription factors and their upstream signaling events. (a) The levels of transcription factors (p65, c-Jun, and c-Fos) in the nuclear fraction were determined using Western blot analysis of antibodies against total protein. ((b), (c), and (d)) Phosphoprotein or total protein levels of ERK, p38, JNK, MKK3/6, MKP-1, and $\beta$-actin from cell lysates were determined using Western blot analysis of phospho-specific or total protein antibodies. (e) The molecular complex formation between MKK3 and p38 or p-p38 was evaluated by immunoprecipitation and immunoblotting analysis.

did not only increase MKP-1 levels to dephosphorylate p38 (Figure 4(d)) but also suppressed the activation of p38phosphorylating MKK3/6 (Figure 4(c)) strongly suggests that there is an indirect inhibitory mode of action that suppresses the p38/c-Jun pathway. Further studies to get insights will be followed in the next experiments.

In summary, we have found that NGACP treatment is able to suppress LPS-induced inflammatory responses such as $\mathrm{NO}$ and $\mathrm{PGE}_{2}$ production in both RAW264.7 cells and peritoneal macrophages at the transcriptional level. According to our immunoblotting and immunoprecipitation analyses, p38/AP-1 could be the major inhibitory pathway in the
NGACP-mediated anti-inflammatory response. Therefore, these results strongly suggest that NGACP treatment could be applied to the treatment of various inflammatory diseases such as arthritis and colitis. To further test this possibility, additional relevant in vivo efficacy tests will be conducted in the future.

\section{Conflict of Interests}

The authors report no conflict of interests. The authors alone are responsible for the content and writing of the paper. 




(a)



(b)

FIGURE 5: Effect of SB203580 on the expression of COX-2 and TNF- $\alpha$ mRNA and the production of TNF- $\alpha$ and PGE . ((a) and (b)) The levels of COX-2 and TNF- $\alpha$ mRNA were determined using semiquantitative RT-PCR or real-time PCR. (a) The levels of TNF- $\alpha$ and PGE 2 were determined using ELISA and EIA on culture supernatants from RAW264.7 cells that had been treated with SB203580 (20 $\mu \mathrm{M})$ and LPS $(1 \mu \mathrm{g} / \mathrm{mL})$ for $6 \mathrm{~h}(\mathrm{TNF}-\alpha)$ or $24 \mathrm{~h}\left(\mathrm{PGE}_{2}\right) \mathrm{h} .{ }^{*} \mathrm{P}<0.05$ and ${ }^{* *} \mathrm{P}<0.01$ compared to control.

\section{Authors' Contribution}

Deok Jeong and Jaehwi Lee contributed to the paper equally.

\section{Acknowledgments}

This research was supported by a Grant (2010-2012) from Kangwon Technopark, Kangwon Province, Korea. Deok Jeong and Jaehwi Lee equally contributed to this work.

\section{References}

[1] R. W. Kinne, R. Bräuer, B. Stuhlmüller, E. Palombo-Kinne, and G. R. Burmester, "Macrophages in rheumatoid arthritis," Arthritis Research, vol. 2, no. 3, pp. 189-202, 2000.
[2] T. Owens, A. A. Babcock, J. M. Millward, and H. Toft-Hansen, "Cytokine and chemokine inter-regulation in the inflamed or injured CNS," Brain Research Reviews, vol. 48, no. 2, pp. 178184, 2005.

[3] J. A. Gracie, R. J. Forsey, W. L. Chan et al., "A proinflammatory role for IL-18 in rheumatoid arthritis," Journal of Clinical Investigation, vol. 104, no. 10, pp. 1393-1401, 1999.

[4] B. Stuhlmuller, U. Ungethum, S. Scholze et al., "Identification of known and novel genes in activated monocytes from patients with rheumatoid arthritis," Arthritis and Rheumatism, vol. 43, no. 4, pp. 775-790, 2000.

[5] E. Michaëlssony, M. Holmdahl, Å. Engström, H. Burkhardt, A. Scheynius, and R. Holmdahl, "Macrophages, but not dendritic cells, present collagen to T cells," European Journal of Immunology, vol. 25, no. 8, pp. 2234-2241, 1995

[6] H. J. Ko, J. H. Jin, O. S. Kwon, J. T. Kim, K. H. Son, and H. P. Kim, "Inhibition of experimental lung inflammation and 
bronchitis by phytoformula containing Broussonetia papyrifera and Ionicera japonica," Biomolecules and Therapeutics, vol. 19, no. 3, pp. 324-330, 2011.

[7] C. G. Leon, R. Tory, J. Jia, O. Sivak, and K. M. Wasan, "Discovery and development of toll-like receptor 4 (TLR4) antagonists: a new paradigm for treating sepsis and other diseases," Pharmaceutical Research, vol. 25, no. 8, pp. 1751-1761, 2008.

[8] Y. Sekine, T. Yumioka, T. Yamamoto et al., "Modulation of TLR4 signaling by a novel adaptor protein signal-transducing adaptor protein-2 in macrophages," Journal of Immunology, vol. 176, no. 1, pp. 380-389, 2006.

[9] K. Takeda and S. Akira, "Roles of Toll-like receptors in innate immune responses," Genes to Cells, vol. 6, no. 9, pp. 733-742, 2001.

[10] B. Bresnihan, "Pathogenesis of joint damage in rheumatoid arthritis," Journal of Rheumatology, vol. 26, no. 3, pp. 717-719, 1999.

[11] G. R. Burmester, B. Stuhlmüller, G. Keyszer, and R. W. Kinne, "Mononuclear phagocytes and rheumatoid synovitis: mastermind or workhorse in arthritis?" Arthritis and Rheumatism, vol. 40, no. 1, pp. 5-18, 1997.

[12] T. J. Kang, J. S. Moon, S. Lee, and D. Yim, "Polyacetylene compound from Cirsium japonicum var. ussuriense inhibits the LPS-induced inflammatory reaction via suppression of NF- $\kappa$ B activity in RAW 264.7 cells," Biomolecules and Therapeutics, vol. 19, no. 1, pp. 97-101, 2011.

[13] R. Beever, "Far-infrared saunas for treatment of cardiovascular risk factors: summary of published evidence," Canadian Family Physician, vol. 55, no. 7, pp. 691-696, 2009.

[14] S. Inoue and M. Kabaya, "Biological activities caused by farinfrared radiation," International Journal of Biometeorology, vol. 33, no. 3, pp. 145-150, 1989.

[15] C. S. Rau, J. C. S. Yang, S. F. Jeng et al., "Far-infrared radiation promotes angiogenesis in human microvascular endothelial cells via extracellular signal-regulated kinase activation," Photochemistry and Photobiology, vol. 87, no. 2, pp. 441-446, 2011.

[16] C. C. Lin, C. F. Chang, M. Y. Lai, T. W. Chen, P. C. Lee, and W. C. Yang, "Far-infrared therapy: a novel treatment to improve access blood flow and unassisted patency of arteriovenous fistula in hemodialysis patients," Journal of the American Society of Nephrology, vol. 18, no. 3, pp. 985-992, 2007.

[17] L. Giangregorio, C. Craven, K. Richards et al., "A randomized trial of functional electrical stimulation for walking in incomplete spinal cord injury: effects on body composition," Journal of Spinal Cord Medicine, vol. 35, no. 5, pp. 351-360, 2012.

[18] N. Shafer and G. Kitay, "Transcutaneous electrical nerve stimulation and pain relief: an overview," Medical electronics, vol. 19, no. 5, pp. 132-136, 1988.

[19] A. Khadilkar, S. Milne, L. Brosseau et al., "Transcutaneous electrical nerve stimulation (TENS) for chronic low-back pain," Cochrane Database of Systematic Reviews, no. 3, Article ID CD003008, 2005.

[20] P. Sarzi-Puttini, M. A. Cimmino, R. Scarpa et al., "Osteoarthritis: an overview of the disease and its treatment strategies," Seminars in Arthritis and Rheumatism, vol. 35, no. 1, pp. 1-10, 2005.

[21] T. J. Berger, J. A. Spadaro, and R. Bierman, "Antifungal properties of electrically generated metallic ions," Antimicrobial Agents and Chemotherapy, vol. 10, no. 5, pp. 856-860, 1976.
[22] T. J. Berger, J. A. Spadaro, S. E. Chapin, and R. O. Becker, "Electrically generated silver ions: quantitative effects on bacterial and mammalian cells," Antimicrobial Agents and Chemotherapy, vol. 9, no. 2, pp. 357-358, 1976.

[23] Y. C. Cho, S. H. Lee, M. Lee et al., "Enhanced IL-12p40 production in LPS-stimulated macrophages by inhibiting JNK activation by artemisinin," Archives of Pharmacal Research, vol. 35, no. 11, pp. 1961-1968, 2012.

[24] J. Y. Cho, K. U. Baik, J. H. Jung, and M. H. Park, "In vitro antiinflammatory effects of cynaropicrin, a sesquiterpene lactone, from Saussurea lappa," European Journal of Pharmacology, vol. 398, no. 3, pp. 399-407, 2000.

[25] T. Yayeh, K. H. Jung, H. Y. Jeong et al., "Korean red ginseng saponin fraction downregulates proinflammatory mediators in LPS stimulated RAW264. 7 cells and protects mice against endotoxic shock," Journal of Ginseng Research, vol. 36, no. 3, pp. 263-269, 2012.

[26] R. Pauwels, J. Balzarini, M. Baba et al., "Rapid and automated tetrazolium-based colorimetric assay for the detection of antiHIV compounds," Journal of Virological Methods, vol. 20, no. 4, pp. 309-321, 1988.

[27] T. Shen, J. Lee, M. H. Park et al., "Ginsenoside $\mathrm{Rp}_{1}$, a ginsenoside derivative, blocks promoter activation of iNOS and Cox-2 genes by suppression of an IKK $\beta$-mediated NF- $\kappa$ B pathway in HEK293 cells," Journal of Ginseng Research, vol. 35, no. 2, pp. 200-208, 2011.

[28] J. R. Kim, D. R. Oh, M. H. Cha et al., "Protective effect of polygoni cuspidati radix and emodin on Vibrio vulnificus cytotoxicity and infection," Journal of Microbiology, vol. 46, no. 6, pp. 737-743, 2008.

[29] Y. O. Kim and S. W. Lee, "Microarray analysis of gene expression by ginseng water extracts in a mouse adrenal cortex after immobilization stress," Journal of Ginseng Research, vol. 35, no. 1, pp. 111-123, 2011.

[30] J. Kwon, S. Kim, S. Shim, D. S. Choi, J. H. Kim, and Y. B. Kwon, "Modulation of LPS-stimulated astroglial activation by ginseng total saponins," Journal of Ginseng Research, vol. 35, no. 1, pp. 80-85, 2011.

[31] M. K. Shim and Y. J. Lee, "Estrogen receptor is activated by Korean red ginseng in vitro but not in vivo," Journal of Ginseng Research, vol. 36, no. 2, pp. 169-175, 2012.

[32] J. A. Lee, M. Y. Lee, I. S. Shin, C. S. Seo, H. Ha, and H. K. Shin, "Anti-inflammatory effects of Amomum compactum on RAW 264. 7 cells via induction of heme oxygenase-1," Archives of Pharmacal Research, vol. 35, no. 4, pp. 739-746, 2012.

[33] Y. G. Lee, W. M. Lee, J. Y. Kim et al., "Src kinase-targeted anti-inflammatory activity of davallialactone from Inonotus xeranticus in lipopolysaccharide-activated RAW264.7 cells," British Journal of Pharmacology, vol. 154, no. 4, pp. 852-863, 2008.

[34] H. D. Kim, S. E. Ha, J. R. Kang, and J. K. Park, "Effect of Korean red ginseng extract on cell death responses in peroxynitritetreated keratinocytes," Journal of Ginseng Research, vol. 34, no. 3, pp. 205-211, 2010.

[35] T. Matt, "Transcriptional control of the inflammatory response: a role for the CREB-binding protein (CBP)," Acta Medica Austriaca, vol. 29, no. 3, pp. 77-79, 2002.

[36] R. A. Hipskind and G. Bilbe, "MAP kinase signaling cascades and gene expression in osteoblasts," Frontiers in Bioscience, vol. 3, pp. d804-d816, 1998.

[37] Y. Terada, O. Nakashima, S. Inoshita, M. Kuwahara, S. Sasaki, and F. Marumo, "Mitogen-activated protein kinase cascade and 
transcription factors: the opposite role of MKK3/6-p38K and MKK1-MAPK," Nephrology Dialysis Transplantation, vol. 14, no. 1, pp. 45-47, 1999.

[38] L. Li, S. F. Chen, and Y. Liu, "MAP kinase phosphatase-1, a critical negative regulator of the innate immune response," International Journal of Clinical and Experimental Medicine, vol. 2, no. 1, pp. 48-67, 2009.

[39] F. M. Ho, C. C. Lai, L. J. Huang, T. C. Kuo, C. M. Chao, and W. W. Lin, "The anti-inflammatory carbazole, LCY-2-CHO, inhibits lipopolysaccharide- induced inflammatory mediator expression through inhibition of the p38 mitogen-activated protein kinase signaling pathway in macrophages," British Journal of Pharmacology, vol. 141, no. 6, pp. 1037-1047, 2004.

[40] S. Kaur, P. Lyte, M. Garay et al., "Galvanic zinc-copper microparticles produce electrical stimulation that reduces the inflammatory and immune responses in skin," Archives of Dermatological Research, vol. 303, no. 8, pp. 551-562, 2011.

[41] I. S. Kim, J. K. Song, Y. M. Song et al., "Novel effect of biphasic electric current on in vitro osteogenesis and cytokine production in human mesenchymal stromal cells," Tissue Engineering A, vol. 15, no. 9, pp. 2411-2422, 2009.

[42] C. Erridge, "Endogenous ligands of TLR2 and TLR4: agonists or assistants?" Journal of Leukocyte Biology, vol. 87, no. 6, pp. 989-999, 2010.

[43] E. Dupont, C. Cieniewski-Bernard, B. Bastide, and L. Stevens, "Electrostimulation during hindlimb unloading modulates PI3K-AKT downstream targets without preventing soleus atrophy and restores slow phenotype through ERK," American Journal of Physiology, vol. 300, no. 2, pp. R408-R417, 2011.

[44] S. Morino, T. Kondo, K. Sasaki et al., "Mild electrical stimulation with heat shock ameliorates insulin resistance via enhanced insulin signaling," PLoS One, vol. 3, no. 12, Article ID e4068, 2008.

[45] T. Koga, Y. Kai, R. Fukuda et al., "Mild electrical stimulation and heat shock ameliorates progressive proteinuria and renal inflammation in mouse model of alport syndrome," PLoS One, vol. 7, no. 8, Article ID e43852, 2012. 


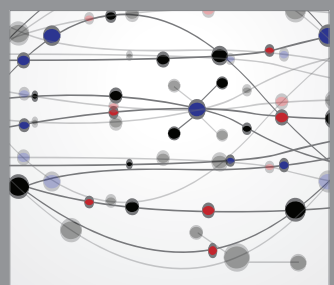

The Scientific World Journal
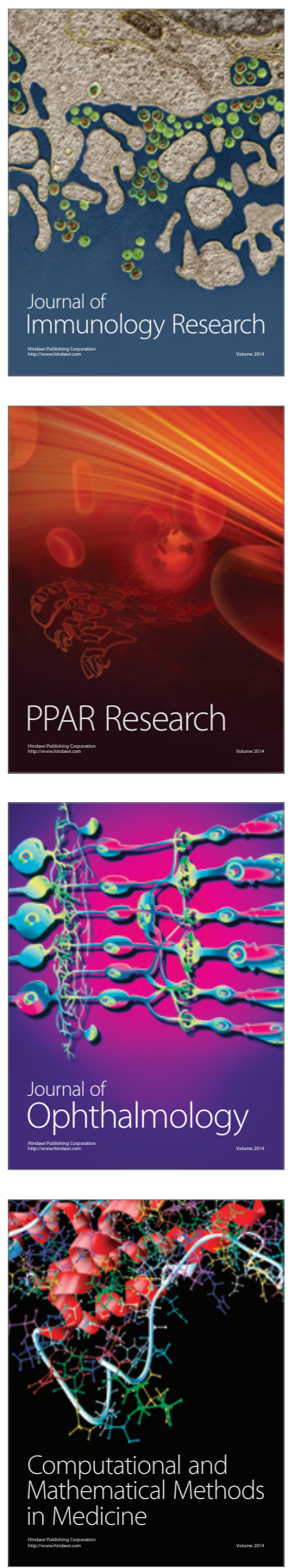

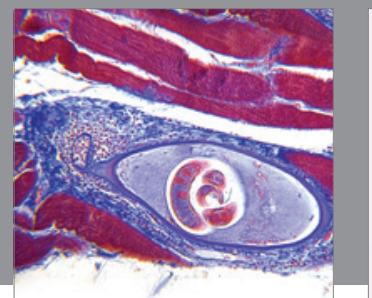

Gastroenterology

Research and Practice
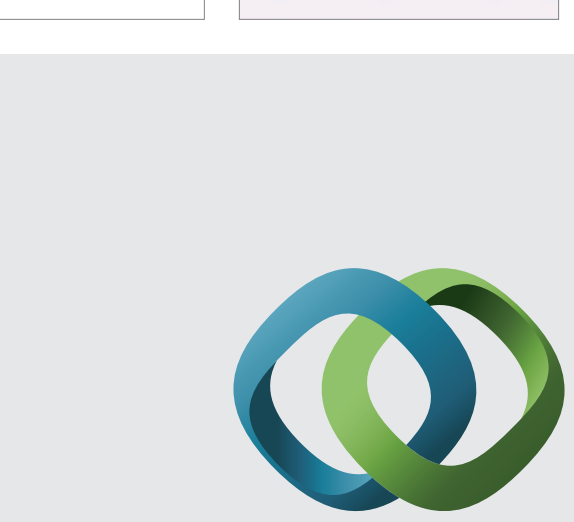

\section{Hindawi}

Submit your manuscripts at

http://www.hindawi.com

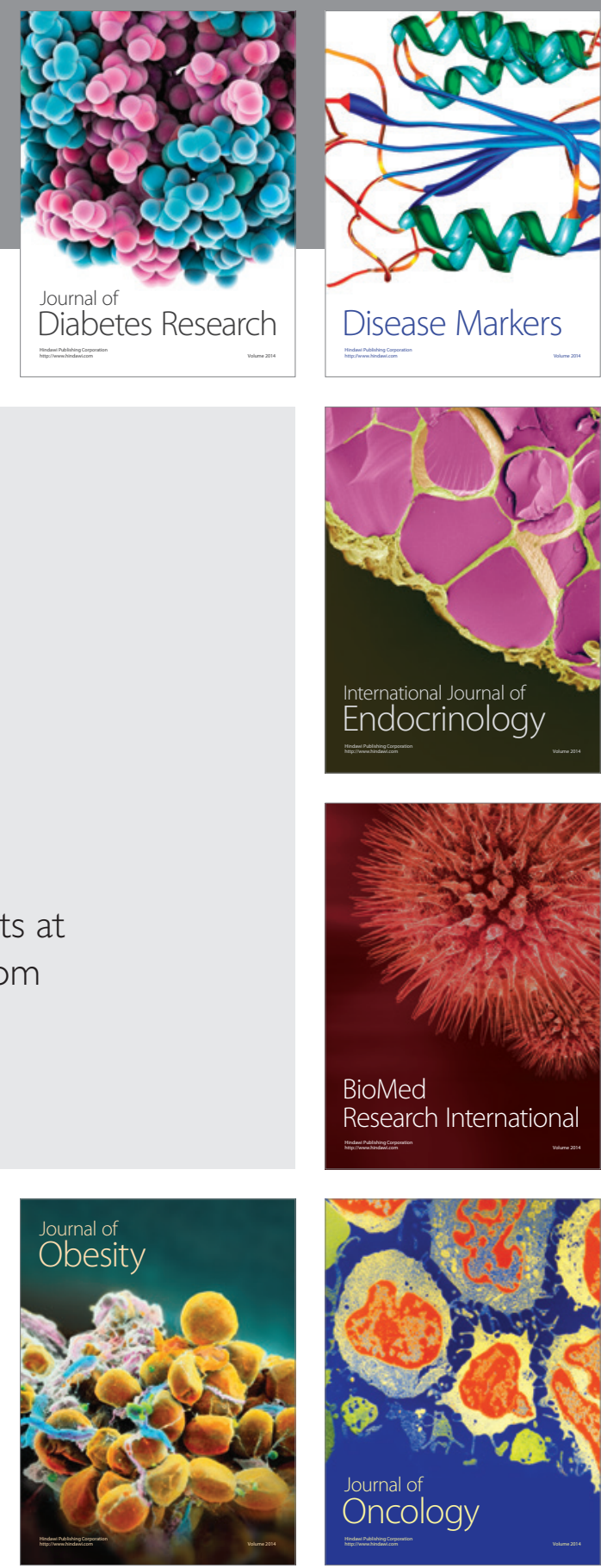

Disease Markers
